\title{
Investigation in the Interethnic Relations in the Republic of Tatarstan: Teaching Methods of the Adaptation of the Local Population to the Presence of Migrants
}

\author{
Tatyana A. Titova ${ }^{1}$, Elena V. Frolova ${ }^{1}$, Elena G. Guschina ${ }^{1} \&$ Bulat I. Fakhrutdinov ${ }^{1}$ \\ ${ }^{1}$ Kazan Federal University, Russian Federation, 420080, Kazan, Kremlin Street, 18 \\ Correspondence: Tatyana AlekseevnaTitova, Kazan Federal University, Russian Federation, 420080, Kazan, \\ Kremlin Street, 18. E-mail: tatiana.titova@rambler.ru
}

Received: July 17, 2019

Accepted: September 10, 2019

Online Published: October 28, 2019

doi:10.5430/ijhe.v8n7p8

URL: https://doi.org/10.5430/ijhe.v8n7p8

\begin{abstract}
The relevance of the research is determined by the problem of interethnic relations in the multi-ethnic and multi-confessional regions of the Russian Federation. The purpose of the article is to describe the attitude of the local population to wards migrants of different cultures in their settlements in the Republic of Tatarstan in 2017. The leading approach in studying this problem is multi paradigmatic methodology. The article incorporate the attitude of the local population to the presence of migrants in the Republic of Tatarstan in 2014-2017, provides the comparative data on major cities and towns of the Republic, helps grasping the issue. The authors paid special attention to the general level of pupils. The results of the article can be useful for ethnologists, social and cultural anthropologists, political scientists, as well as for the representatives of the bodies responsible for the inter-ethnic interaction.
\end{abstract}

Keywords: interethnic relations, migration, multi-ethnicity, training the socialization, cultural norms

\section{Introduction}

The Republic of Tatarstan is historically one of the multi-ethnic and multi-faith regions of the Russian Federation. In modern times, the migration processes are playing an ever-increasing role in the economic, social, and political development of the Republic of Tatarstan. The relevance of studying the adaptation parameters of the local community to the migrants is determined by the needs of the multi-ethnic and multi-confessional society of the Republic of Tatarstan. The interaction of the local population and migrants has an impact on the socio-economic development of the society, the daily people practices, the general state of interethnic and interconfessional relations.

The inter-ethnic and inter-confessional relations in the society occur at two levels: institutional and intergroup. The institutional level is studied mainly by ethnopolitologists (Tishkov, Shabaev, 2011), the intergroup level is studied by ethno-sociologists (Drobizheva et al., 2016; Mambile \& Machuve, 2018; Akbari et al, 2018; Hassan et al, 2019).

In Ethno-sociology the inter-ethnic interaction is studied through opinions, attitudes, orientations, values of people in different spheres of life: in business, industry, leisure, family.

The inter-ethnic and interfaith relations as a part of the daily and professional life of people cause a wide range of problems, studying and solution of which seem relevant and advanced.

\section{Methodological Framework}

The study is based on the methodological principles of the multi paradigmatic approach. Our research is based on the two principles of F. Barth's theory: the first concept is that the social factors underlying the phenomenon of categorical attribution but not the "objective" cultural differences become determinant for a group membership. Secondly, ethnic categories both in identifying themselves and while attributing others to certain ethnic groups, take into account not the sum of objective differences, but only those ones that are perceived by the individuals as significant (Barth, 1989).

The research is based on the analysis of the empirical data of 2014-2017. The data was collected by surveying the representatives of major ethnic groups in the region (the Tatars and the Russians), observation, semi-structured and biographical interviews. The data submission is based on the principles of the so-called "detailed description"- a kind of analysis that is carried out in terms of the informants. 


\section{Results}

The research shows that compared to the data of 2016the proportion of the respondents who opposed the presence of migrants in their locality has slightly increased (from $8.1 \%$ in 2016 to $12.2 \%$ in 2017). The largest percentage of such respondents is in Chistopol (22\%) and NaberezhnyeChelny (19.3\%). The proportion of those who declare an indifferent attitude towards migrants has significantly increased (see Table 1).

Table 1. The answers to the question: "How do you feel about the presence of migrants in your locality?"(according to the studies in 2014, 2015, 2016, 2017), \%

\begin{tabular}{|c|c|c|c|c|c|}
\hline & 20142. & 20152. & 20162. & 20172. & \\
\hline $\begin{array}{l}\text { Totally against their } \\
\text { presence }\end{array}$ & 10,1 & 11,6 & 8,1 & $\begin{array}{l}\text { Totally against their } \\
\text { presence }\end{array}$ & 12,2 \\
\hline $\begin{array}{l}\text { I agree if there are as few } \\
\text { of them as possible }\end{array}$ & 26,5 & 20,8 & 19,5 & & \\
\hline $\begin{array}{l}\text { I agree if they behave like } \\
\text { locals }\end{array}$ & 33,9 & 38,8 & 36,7 & $\begin{array}{l}\text { Agree under some } \\
\text { conditions }\end{array}$ & 46,4 \\
\hline $\begin{array}{l}\text { I agree if they speak } \\
\text { Russian }\end{array}$ & 8,9 & 6,7 & 10,5 & & \\
\hline I do not care & 10,3 & 10,3 & 15,4 & I do not care & 25,7 \\
\hline I have a positive attitude & 4,9 & 7,9 & 6 & $\begin{array}{l}\text { I } \\
\text { have a positive attitude }\end{array}$ & 9,3 \\
\hline No answer & 5,4 & 4 & 3,7 & No answer & 6,5 \\
\hline
\end{tabular}

$21.3 \%$ of the respondents who agree with the presence of migrants under certain conditions, consider that there should be as few migrants as possible (in Chistopol there are 34\% of such respondents, in Mamadysh - 25\%, in NaberezhnyeChelny $-21.3 \%$, in Kazan $-16.4 \%$ ).

In general, the increasing number of immigrants is one of the main factors causing discomfort:

From the interview: "I don't like too many of them. The country should not be burdened with too many immigrants. They are all different. Some of them are impudent. I have not come across such people in my neighborhood, but sometimes I have met such "individuals" who demand too much." (male, 35 years old, Tatar, NaberezhnyeChelny)

$65.6 \%$ locals who agree with the presence of migrants under certain conditions believe that migrants should behave like locals (73.3\% of the respondents in Laishevo, 67.7\% in Nizhnekamsk, more than 50\% in Kazan and Mamadysh, $48.8 \%$ in NaberezhnyeChelny, $37.7 \%$ in Chistopol).

About a third of the respondents (32.7\%) believe that the immigrants should first speak Russian. The Russian respondents point out that the migrants should learn Russian (38.8\% of the Russian and $27 \%$ of the Tatar people).

In informal interviews the respondents explained their positions:

"The immoral conduct of immigrants, the inconsistency of their behavior with the norms adopted in the local community";

"There is an expression: "When in Rome, do as the Romans do"- if the immigrants have arrived, they must accept the requirements of the country and do not dictate the terms";

"There are too many of them, it is impossible to live peacefully."

"They do not respect the local population; they speak Russian poorly."

Therefore, as in previous years, the respondents consider that migrants should abide by the cultural norms of the host community, "behave like the locals".

From an interview: "I am neutral to them. The most important thing is to observe our traditions... Well, sometimes they allow themselves too much. Taking into consideration what we provide them with. We say that they cannot behave inappropriately and should behave properly. They seem to be listening to our opinion, at least in our neighborhood. (female, Tatar, 35 years old, Kazan).

"I don't want to sound nationalistic, but my attitude is extremely negative: not only do they come but they bring their own laws and do not want to live according to ours. It could be different. But they come here, they are absolutely 
asocial, most of them have children who are unaffected by education, they are difficult to teach, to bring up. I cannot say that they are job-killers or something, but they mostly have many children and they are already using our Russian laws to support themselves... (focus group, Kazan).

$31.3 \%$ believe that about half of the residents of the Republic share their opinion about migrants, $29.7 \%$ think that the majority of people in the Republic think the same.

From the interview: "I think a lot of people think the same. Especially about the number of people coming here. This is vivid. I understand that there are not enough workers at many companies, factories. Young people don't go there eagerly. But we need to attract young locals so that our people could also work, not just create vacancies for the new comers. Although, you know, there area lot of our compatriots living abroad. And they kill someone else's job there. So, somewhat like balance is kept. (male, 35 years old, Tatar, NaberezhnyeChelny)

The migrants themselves are more optimistic about locals' attitude towards them:

"Excellent, good, because the people here are friendly and nice. We have good relationships. We share our minds, tell them about something, sometimes they even sympathize, for example when you go to a residents' registration office. There can be some problems with the documents. Oh, yes, it is everywhere hard for visitors. Of course, they sympathize, try to give good advice. Well, I think everything is ok, thank God. The people are fine." (focus group, NaberezhnyeChelny).

The respondents are unaware of the areas of compact settlement of migrants in their location: only $7.5 \%$ of the respondents know about them ( $11 \%$ in 2016).

About a third of them have "neutral" attitude towards the places of compact residence, a quarter of them is strongly against (see Table 2).

Table 2. "How do you feel about the places of compact residence for migrants in your settlement?" (2015, 2016, 2017), \%

\begin{tabular}{llll}
\hline & 2015 & 2016 & 2017 \\
\hline $\begin{array}{l}\text { Neutrally,they do not disturb } \\
\text { me }\end{array}$ & 34,7 & 43,8 & 34 \\
$\begin{array}{l}\text { The existence of such places } \\
\text { makes me irritated as this is }\end{array}$ & 16,8 & 13,5 & 13,9 \\
the concentration of people of & & \\
a different culture & 42,1 & 22 & 25,4 \\
$\begin{array}{l}\text { I am totally against such } \\
\text { places }\end{array}$ & 6,3 & 20,7 & 26,8 \\
It is difficult to say & 4
\end{tabular}

Answering the question: "How will you react to your child making friends with the children of migrants?" $57.9 \%$ of the respondents said they would not be against such friendship.

At the same time, $22.7 \%$ pointed out that they would not approve of the friendship of their child with the children of migrants. The share of such respondents is higher in Chistopol (38\%); in Nizhnekamsk - 30.7\%, in Laishevo - 28\%, in NaberezhnyeChelny - 24.7\%, in Kazan - 20.3\%, in Mamadysh - 4\%.

The problems connected with the socialization of migrants' children were articulated by respondents in focus groups:

"I would also add: they are coming and their children are not socialized, they do not go to kindergartens, because they should pay for it but the school is free. They have kicked their children out and they don't care: those children come to school without books, without notebooks, without anything; the parents do not come to school to find out how their children are doing, they do not even come on call. They have kicked the children out and believe that they are getting an education. And these children spoil our statistics, we in the world are working with them, but it's all down the drain. There are few parents who want and watch. And the parents are not registered. "(focus group, Kazan)

$21 \%$ of the respondents believe that the presence of legal labor migrants has a positive effect on the Republic economy; $20 \%$ observe a negative impact, $33.5 \%$ do not see a significant effect, $24.8 \%$ found it difficult to answer.

In informal statements the respondents explained: 
"There is a big competition in the agricultural markets and people select for migrants (cheap price) but the quality leaves much to be desired";

"The majority of citizens are left without jobs";

"A large number of migrants bring the rise of crime";

"In our republic, there is a fairly stable economic situation, we do not need additional labor power";

"First of all, they need to fix up the unemployed residents for a job and only then welcome migrants."

$33.2 \%$ believe that it is necessary to restrict the entry of legal labor migrants into the Republic.

A significant number of respondents have difficulty in evaluating the authorities work with migrants. $42.3 \%$ of the respondents evaluated the work of the authorities "positively" and "quite positively",17.9\% evaluated "negatively" and "rather negatively", about $40 \%$ found it difficult to answer.

Speaking of the willingness of migrants to integrate into the host community the respondents note that migrants do not communicate well with the representatives of the host population explaining this by a low level of inter-group trust:

From the interview: "Migrants feel... even time later... judging by their neighbors... they feel rather uncomfortable. Although they are sufficiently protected, and I think they feel uncomfortable as they are visitors and their national traditions do not allow them to live the way they do it at home. They are quite shy. For example, my neighbors are men, we often bump into each other at the stairwell, and although we greet each other, they do not establish a contact. Perhaps they may be still afraid of some kind of document checks, some kind of unfriendly attitude toward them. Perhaps they shun people who they have once dealt with. Nevertheless, they are not immune to dishonest employers and to deceitful and evil people. " (male, born in 1984, Tatar, Kazan)

The differences in behavioral practices are also mentioned by migrants themselves:

"There is very little communication, you don't really know your neighbors, you're not making friends. We live differently, of course: we have too close relations with relatives, with neighbors, here people are distant. "(focus group, Kazan)

\section{Discussions}

The research of the migration processes in the Russian Federation may be important for the representatives of various scientific fields. Sociologists study the ethnic-social and ethnic -confessional aspects of migration in modern society (Tishkov, 2003; Drobizheva, 2009). Political scientists are studying the problems of the influence of the inter-ethnic relations on state policy and social processes (Abdulatipov, 2004; Suleri \& Cavagnaro, 2016). The psychological aspects of cross-ethnic interaction occupy a special place(Stefanenko, 2003). The researchers are interested in the inter-group distance between the host population and groups of migrants, the level of xenophobia, the features of social contacts between representatives of different nationalities. Anthropologists and ethnologists study the everyday practices of inter-ethnic and interfaith interactions. The analysis focuses, in particular, on the study of social inter-group distance in a multi-ethnic community (Titova, Sabirova, Frolova, 2016). At the same time, the study of the features of multi-ethnic and interfaith interaction in the regions of the Russian Federation requires more careful study. In this study, the researchers studied the indicators of the local population adaptation to the presence of migrants.

\section{Conclusions}

The problem of ethnic boundaries between the host population and migrants at the level of group and individuals still exists.

The representatives of the host population believe that migrants have an opportunity to participate in the economic, social and cultural life of their settlement and they feel comfortable.

The adaptation of the host population to the presence of migrants is limited by several factors:

- cultural orientations of migrants, according to the respondents, are in conflict with the host population orientations;

- the level of inter-group trust between the host population and migrants remains quite low;

- the increase in the number of migrants causes discomfort and a latent feeling of losing dominance among the local population.

At the same time, the immigrants are more optimistic than the local residents in evaluating the attitude towards them by residents. 


\section{Recommendations}

The submitted results of the study may have scientific, humanitarian and practical value. The materials of the article can be useful for the specialists in the field of social sciences: ethnologists, social and cultural anthropologists, political scientists as well as the representatives of the state bodies responsible for a migration policy and multi-ethnic interaction.

\section{Acknowledgements}

The work is performed according to the Russian Government Program of Competitive Growth of Kazan Federal University.

\section{References}

Abdulatipov, R.G. (2004). Ethnopolittology. St. Petersburg: Peter.

Akbari, A., Abbasian, M. \& Jansooz, P. (2013). Application of RAP Model in measuring the capabilities of attracting sources in the economy, A case study of the tourism sector in Sistan and Balucestan. UCT Journal of Social Sciences and Humanities Research, 1(1), 16-21.

Barth, F. (1989). Analysis of Culture in Complex Societies. Ethnos, 4, 120-142.

Drobizheva, L. M. (2009). Russian identity in Moscow and regions. M., Institute of Sociology, Russian Academy of Sciences.

Drobizheva, L. M., Arutyunova, E. M., Evseyeva, M. A., Kozlov, V. E., Kuznetsov, I. M., Mukomel, V. I., Ryzhova, S. V., Titova, T. A. \& Frolova, E. V. (2016). Positive inter-ethnic relations and the prevention of intolerance, the experience of Tatarstan in the all-Russian context. M.; SPb., Nestor Story.

Hassan, M. N., Abdullah, A. H., Ismail, N., Suhud, S. N. A. \& Hamzah, M. H. (2019). Mathematics Curriculum Framework for Early Childhood Education Based on Science, Technology, Engineering and Mathematics (STEM). International Electronic Journal of Mathematics Education, 14(1), 15-31. https://doi.org/10.12973/iejme/3960

Mambile, C. \& Machuve, D. (2018). Web based Approach to Kurmanali, A., Suiyerkul, B., Aitmukhametova, K., Turumbetova, Z. \& Smanova, B. (2018). Analysis of the proverbs related to the lexemes" tongue/language", Opción, 34(85-2), 97-115. overcome the Market Information Gap between poultry farmers and potential buyers in Tanzania.

Stefanenko, T. G. (2003). Ethnopsychology. M., Academ-Project.

Tishkov, V. A. \& Shabaev, Yu. P. (2011). Ethnopolitology, the political functions of ethnicity. M., Publishing House of Moscow University.

Suleri, J. \& Cavagnaro, E. (2016). Promoting pro-environmental printing behavior, The role of ICT barriers and sustainable values, International Journal of Education and Development using ICT, 12(2).

Tishkov, V. A. (2003). Requiem for Ethnos, Research on Socio-Cultural Anthropology. M., Science, 2003.

Titova, T. A., Sabirova, A. N. \& Frolova, E. V. (2016). Collective social and cultural distance in the sphere of interethnic relations in the Republic of Tatarstan. The Turkish Online Journal of Design, Art and Communication, 6, November Special Edition, 2817-2822. 